\title{
APPLICATION OF SOKOLKA COMPOST TO PROTECT PESTICIDE GRAVEYARD AREA
}

\author{
Katarzyna Ignatowicz' ${ }^{1}$ Jacek Piekarski
}

1 Department of Technology in Engineering and Environmental Protection, Białystok University of Technology, Wiejska 45a, 15-351 Białystok, Poland, e-mail: k.ignatowicz@pb.edu.pl

2 Department of Water-Sludge Technology and Waste Utilization, Koszalin University of Technology, Śniadeckich 2, 75-543 Koszalin, Poland, e-mail: jacek@wbiis.tu.koszalin.pl

Received: 2014.10.30

Accepted: 2014.11.14

Published: 2015.01.02

\begin{abstract}
The paper presents the results of the researches in sorption process. Selected waste materials were checked to build a barrier for pesticide migration from existing graveyards. Due to primary researches Sokolka compost was selected for further researches. The sorption barrier was designed by the surface and underground water run-off. The line of the barrier was made around the centre of graveyard, 0.5 meter width and 4.0 meters deep up to the non-permeable ground layer. GC analyses have shown the presence of pesticides in piezometer before the barrier and no pesticides in water outside sorption barrier. Due to researches it was found that prevention barrier was successful.
\end{abstract}

Keywords: sorption, pesticide, compost.

\section{INTRODUCTION}

Useless plant protection means and the packaging are one of the most dangerous chemical contaminants for environment. The problem is serious in former Soviet Union countries: Armenia, Belarus, Moldova, Kazakhstan, Kyrgyzstan, Uzbekistan, Ukraine, and Russia, but also in Albania, Romania, Turkey, and Poland. [Sofia 2005; Feng 2003; Ignatowicz 2007a, 2007b, 2007c, 2008c; Li 2012; Siłowiecki 2003] Landfills with outdated and useless plant protection means are the largest threat for natural environment resulting from agriculture chemization. For many years, burial sites and water quality in the vicinity have been one of the most difficult problems to solve, which have made enormous harm to a man and natural environment. Large amounts of useless plant protection means in 1960's were one of the reasons to build waste repositories in Poland. Such a situation intensified in 1970's, when part of means considered as harmful, was withdrawn from use. Burial sites were most often constructed from concrete circles insulated using tar or adhesive; old military objects, such as bunkers or fortifications were also adapted. No hydrological recognition of an area was made during the waste repository localization - usually, remote sites were selected. The problem attracted some attention in 1990's, when burial sites were considered as objects harmful for natural environment due to leakages of outdated pesticides into the environment, which resulted in the environment pollution. Therefore, activities aiming at cataloguing the waste repositories have been undertaken. According to Polish Geological Institute, the number of waste repositories and burial sites filled with outdated pesticides amounted to 284 in 2003 in Poland [Siłowiecki 2003]. Ministry of Environment estimated (before 2009) that about $13.9 \mathrm{Mg}$ of harmful substances are deposited. According to cataloguing carried out in 2009 by Regional Directorates of Environment Protection and the data updated and published by Ministry of Agriculture in July 2010, that number increased almost 200-fold up to $2567.81 \mathrm{Mg}$. In West-Pomerania province, there are 19 burial sites with $1010.9 \mathrm{Mg}$ of deposited wastes, whereas in Podlasie province - 10 waste repositories, including 5 intended for liquidation and contain- 
ing $18.41 \mathrm{Mg}$ of pesticides. The construction of waste repositories gets worse and worse every year, which makes a considerable threat to natural environment contamination and also may be a harm for inhabitants in the vicinity, because contaminants penetrating the environment are invisible. Ground and surface waters as well as soils become polluted as a consequence of pesticide wastes penetration from leaky burial sites. Leakage, when reaches the water-carrying layers, is transported along the underground water streams and may be seized by surface waters. Therefore, activities aiming at eliminating the burial sites are undertaken, although they should be made in reliable way and in accordance to the current state of knowledge. Having no external funds, owners of waste repositories refuse to eliminate them at their own expense, which reaches even hundreds of thousand PLZ. Every object should be considered individually, thus examination of natural waters quality is performed to evaluate their contamination and transport of chemical contaminants in the vicinity. In the case of corrosion and damage of waste repository, a continuous supply of contaminants into the open waters is and will be observed for many years. [Biziuk 2009; Ignatowicz 2007b; Li 2012].

It should be remembered that even if the burial site is removed, the effects of storing toxic substances will be noticeable for many years, both in soil and waters. Therefore, it is necessary to search for means of reducing the pesticide migration within the environment and introducing new solutions.

\section{METHODOLOGY}

The research aimed at developing the new, low-cost technology for reducing toxic substances penetration from waste repositories into environment. All this inspired the author to carry out the study on applying the sorption process on selected waste materials that can be used as a barrier for chemicals penetration into the environment in order to reduce their migration from existing burial sites and waste repositories. The wastes can be also used for land reclamation by filling the pits made after dump storage liquidation, thus creating conditions appropriate for energetic plant species grown on contaminated areas.

The study has been carried out since 2000 and included several stages:
1) Qualitative and quantitative evaluation of pesticide remains in water and soil environments in the vicinity of burial ground;

2) Evaluation of different waste materials usefulness for sorption of pesticides stored within burial grounds;

3) Actual-scale applied research in working burial ground.

\section{RESULTS}

Qualitative and quantitative determination of pesticide remains in environmental elements adjacent to burial grounds

Analyses of plants, soils (up to $30 \mathrm{~m}$ distance from burial ground), natural waters, including drinking water for neighboring inhabitants (up to $2 \mathrm{~km}$ from burial ground) were performed in the direct vicinity of an outdated pesticides store. Material for study was collected in spring during thawing and heavy rainfalls; other seasons - during storms. Not filtered water samples were subject to determinations for 47 biologically active substances representing various chemical groups of pesticide remains: organochlorine, organophosphorus, pyrethroids, nitrophenols, triazines, and phenoxyacids, being components of the most often stored agents. The water samples were also subject to determine heavy metals that were also sometimes constituents of plant protection means (e.g. in organomercuric pesticides): aluminum, arsenic, boron, barium, beryllium, bismuth, cadmium, cobalt, chromium, copper, iron, gallium, mercury, lithium, manganese, molybdenum, nickel, lead, selenium, strontium, thallium, vanadium, and zinc [Ignatowicz 2007a, 2007b, 2007c].

Pesticide concentrations in all samples were determined in accordance with methodology obligatory in a certified laboratory by means of gas chromatograph AGILENT6890 applying ECD1 and NPD2 columns. Moreover, after sample digestion according to EPA 3015 procedure using microwave digester Mars 5, metal concentrations were determined by means of emission atomic spectrophotometry combined with inductively coupled plasma (ICP-AES), although mercury was analyzed with a help of CV-AAS. [Bizuk 2009; Feng 2003; Spadotto 2003; Li 2012, Wiater 2007].

The largest amounts of biologically active substances remains were found in soil samples. Analyzed soil samples contained 10 out of 16 
tested organochlorine substances: pirimicarb, o,pDDT, DDE, p,p-DDT, $\alpha-\mathrm{HCH}, \gamma-\mathrm{HCH}, \delta-\mathrm{HCH}$, $\mathrm{HCB}$, methoxychlor, and endrine [Ignatowicz 2007b, 2007c, 2008a]. These are the most durable and hardly-degradable compounds. The results of soil analysis show that quite a large studied area is contaminated with pesticides originating most likely from non-hermetic chambers of dump or pesticide wastes buried in ground. The presence of insecticides, pyrethroids, and herbicides was found. The achieved contents of pesticides indicate the spreading of pollution within the soil. Buried grounds contained largest amounts of pesticides from organochlorine insecticides group, which is also reflected by the presence of the toxins and their metabolites in the environment surrounding the burial ground in Folwarki Tylwickie. Occurrence of p,p'DDT isomer at concentrations from 0.11 to $0.63 \mu \mathrm{g} / \mathrm{dm}^{3}$ in waters and $136 \mu \mathrm{g} / \mathrm{kg}$ in soils, as well as g-HCH (lindan), which is the hardest degradable of all $\mathrm{HCH}$ metabolites, (0.15$\left.9.0 \mu \mathrm{g} / \mathrm{dm}^{3}\right)$ and $13 \mu \mathrm{g} / \mathrm{kg}$ in soil, is very characteristic. These extremely toxic substances are characterized by long decomposition time and are difficult to biodegrade. Decomposition time of $95 \%$ DDT in the environment is from 4 up to 30 years, while that for $\mathrm{g}-\mathrm{HCH}$ is from 3 to 10 years [Biziuk 2009; Ignatowicz 2007b, 2007c, 2008a].

\section{Evaluating the usefulness of various natural and waste materials for sorption of pesticides dumped in burial grounds}

The studies under static conditions were carried out according to methodology by Chemviron Carbon [Atkin 2006; Ignatowicz 2011a; Spadotto 2003]. They aimed at plotting the adsorption isotherms, due to which a comparison of sorption quantity of different adsorbents on different sorbents can be possible. The analysis of the sorption process was performed on a base of achieved results (applying Statistica software); Freundlich, Langmuir, BET, Huttig, and Dubinin-Raduszkiewicz isotherms were estimated as non-linear models by means of the least squares method with a help of Gauss-Newton or Lovenberg-Marquandt algorithm [Atkins 2006; Ignatowicz 2008b, 2009a, 2011a; Spadotto 2003].

Subsequent study stage, when finding out which pesticide substances migrate into the environment, consisted in a series of experiments aiming at evaluating the usefulness of natural sorbents in reducing this emission. Characterization of applied waste sorbents indicates that they meet conditions for sludge used for natural, including agricultural purposes. [Ignatowicz 2008a, 2008b, 2009a, 2009b, 2011a].

\section{Applied studies in working burial ground}

The results achieved in stages I-II of the study allowed for designing the sorption barrier localized near the burial ground on a line of surface and underground waters outflow, which had to prevent from pesticide migration. The barrier design was described by Ignatowicz [2011b]. the applied study was carried out in 2009 and in 2012 in Folwarki Tylwickie village (Zabłudów commune, Podlasie province). The burial ground is localized in a direct vicinity of the cultivated field. That burial ground was classified into the $1^{\text {st }}$ category of threat.

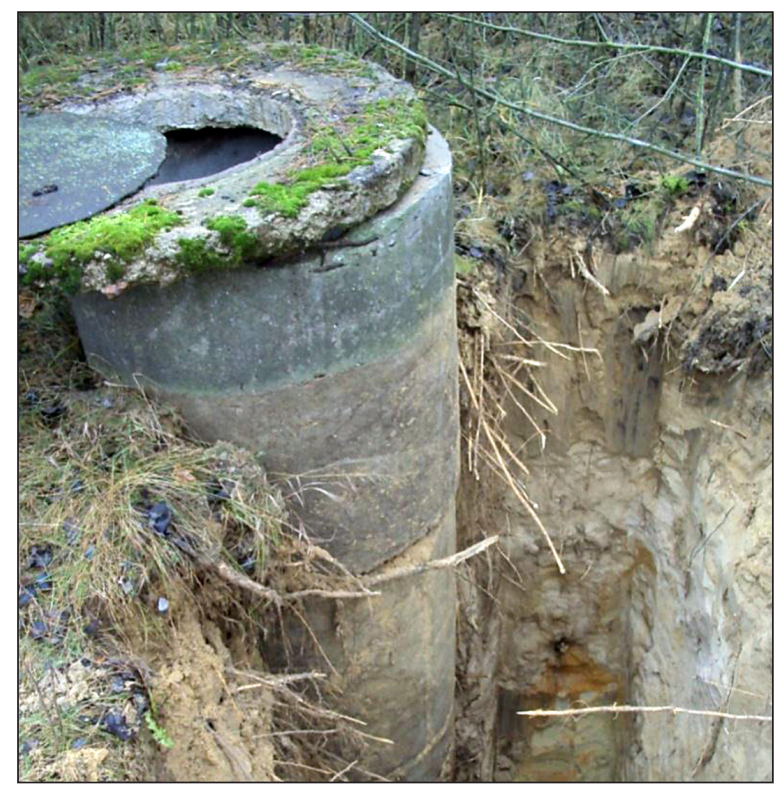

Figure 1. The photo of well's outcrop [Ignatowicz, 2011b]

Water samples were collected from the installed piezometers since the barrier mounting during the heavy rainfalls and snow thawing. Mean values of the results achieved in 2009-2010 were presented by Ignatowicz [2011b]. Minimum and maximum values of achieved results in 2010 2014 were presented in Table 1. The GC analyses revealed that despite of pesticides presence in piezometer just before the barrier, they were absent in waters behind it, thus suggesting that the protective shield satisfied its function. 


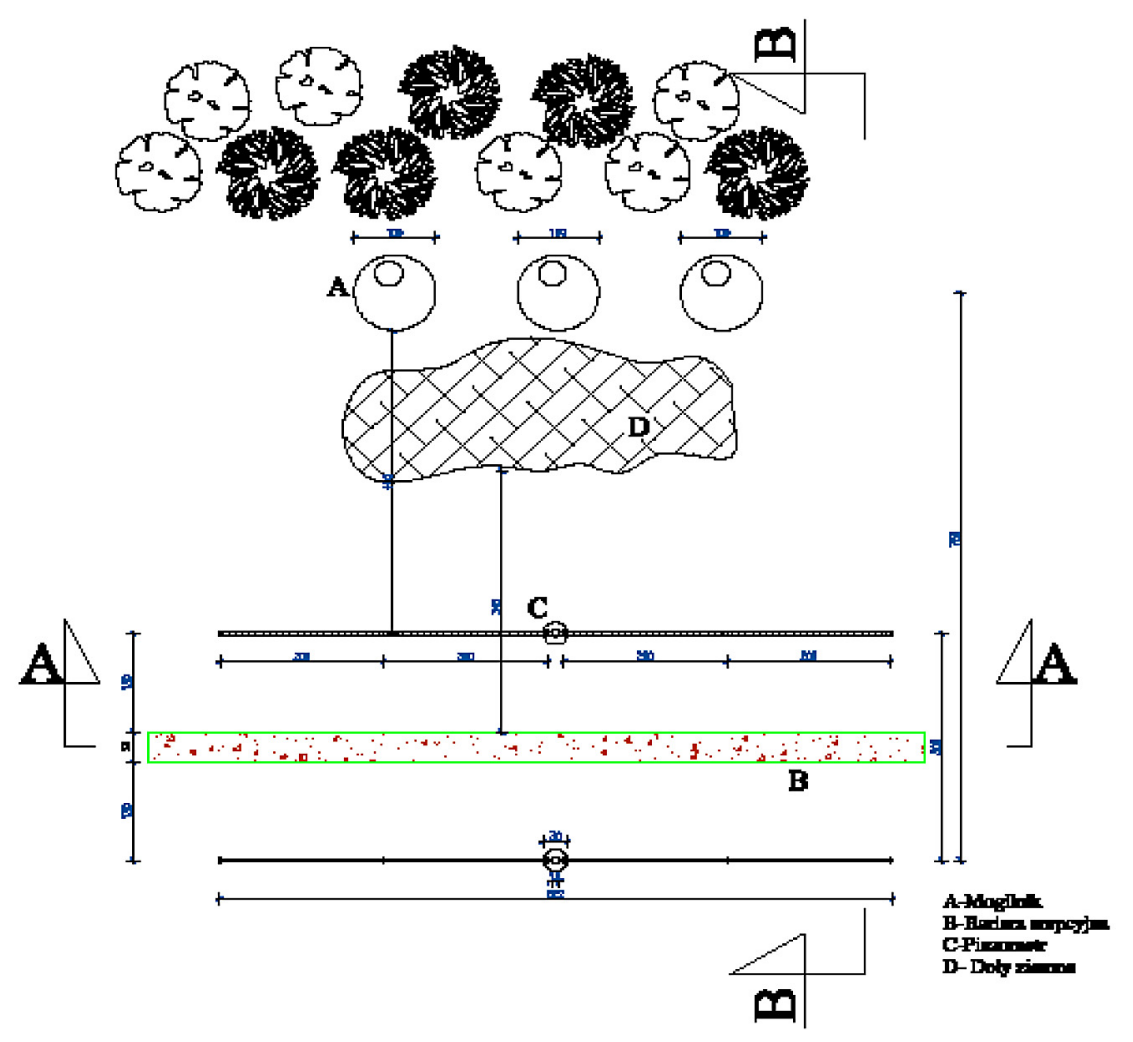

Figure 2. The view of the graveyards area [Ignatowicz 2011b]

Table 1. Concentration of pesticides marked in water samples 2010-2014

\begin{tabular}{|c|c|c|c|c|c|c|c|}
\hline & \multirow[b]{2}{*}{ Pesticide } & \multicolumn{2}{|c|}{ Water $\left[\mu \mathrm{g} / \mathrm{dm}^{3}\right]$} & & \multirow[b]{2}{*}{ Pesticide } & \multicolumn{2}{|c|}{ Water $\left[\mu \mathrm{g} / \mathrm{dm}^{3}\right]$} \\
\hline & & $\begin{array}{c}\text { Piezometers } \\
\text { "before" }\end{array}$ & $\begin{array}{c}\text { Piezometers } \\
\text { "behind" }\end{array}$ & & & $\begin{array}{c}\text { Piezometers } \\
\text { "before" }\end{array}$ & $\begin{array}{c}\text { Piezometers } \\
\text { "behind" }\end{array}$ \\
\hline \multirow{9}{*}{$\mathrm{H}$} & Atrazine & nd & \multirow{23}{*}{ nd } & \multirow{6}{*}{ OC } & HCB & nd & \multirow{23}{*}{ nd } \\
\hline & Chlorpropham & nd & & & $\alpha-\mathrm{HCH}$ & $0,92-0,94$ & \\
\hline & Dichlorprop & nd & & & $\beta-\mathrm{HCH}$ & $0,25-0,29$ & \\
\hline & Dinoseb & nd & & & $\mathrm{Y}-\mathrm{HCH}$ & $9,00-9,89$ & \\
\hline & DNOK & nd & & & $\delta-\mathrm{HCH}$ & $0,06-0,07$ & \\
\hline & MCPA & nd & & & Methoxychlor & $0,22-0,28$ & \\
\hline & Mecoprop & nd & & \multirow{14}{*}{ OP } & Bromfenvinfos & nd & \\
\hline & Simazine & nd & & & Chlorfenvinfos & nd & \\
\hline & $2,4-D$ & nd & & & Chlorpyrifos & nd & \\
\hline \multirow{4}{*}{ IC } & Carbaryl & nd & & & Chlorpyrifos - methyl & nd & \\
\hline & Carbofuran & nd & & & Diazinon & nd & \\
\hline & Pirimicarb & nd & & & Dimethoate & nd & \\
\hline & Propoxur & nd & & & Fenthion & nd & \\
\hline \multirow{10}{*}{$\mathrm{OC}$} & Chlorfenson & nd & & & Fenitrotion & nd & \\
\hline & $p, p^{\prime}-$ DDD & $1,12-1,89$ & & & Heptenophos & nd & \\
\hline & o,p' - DDT & $0,20-0,25$ & & & Izofenphos & nd & \\
\hline & $p, p^{\prime}-\mathrm{DDE}$ & $0,52-0,62$ & & & Methidation & nd & \\
\hline & $p, p^{\prime}-$ DDT & $0,18-0,27$ & & & Parathion & nd & \\
\hline & Dieldrine & $0,12-0,18$ & & & Thiometon & 0,28 & \\
\hline & DMDT & nd & & & Triazophos & 0,94 & \\
\hline & endrine & $0,22-0,25$ & & \multirow{3}{*}{$P$} & Cypermethrin & nd & \\
\hline & $\alpha-\beta$ Endosulfan & $0,65-0,71$ & & & Deltamethrin & nd & \\
\hline & Endosulfan - sulfate & nd & & & Fenpropathrin & nd & \\
\hline
\end{tabular}

nd - not detected. 

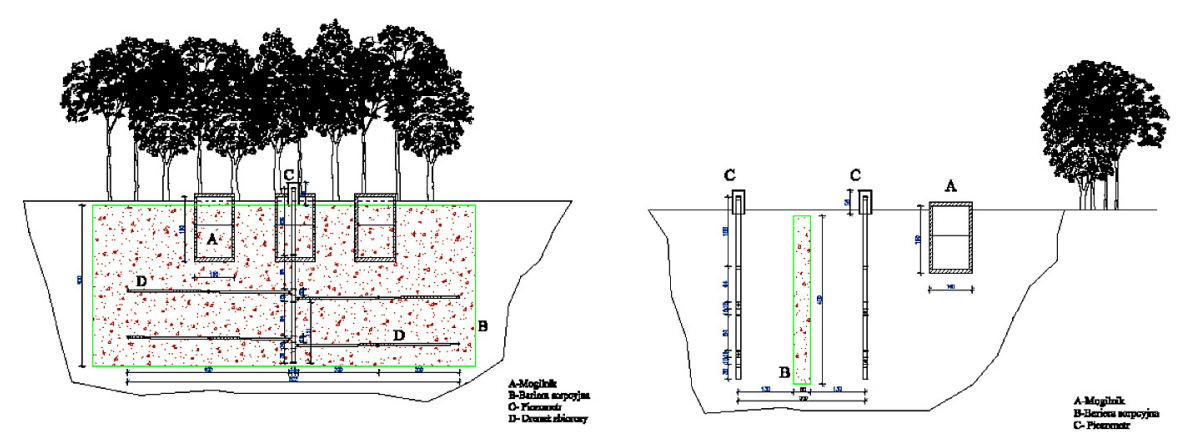

Figure 3. The sectional view of graveyard and sorption barrier. [Ignatowicz 2011b]

\section{CONCLUSION}

The research is a comprehensive cycle of studies around active burial grounds along with a scientific description of a new low-cost technology for reducing penetration of toxic substances from waste dumps into environment, as well as technology of reclamation of closed objects. The research persisted for several years, which allowed for repeating and confirming the achieved results. The results were given to the owners and leaseholders of areas with orchards and crop and horticultural plantations in the vicinity of burial grounds. The cooperation with owners of horticultural and agricultural farms neighboring the pesticide burial grounds, including the owner of Cultivation and Orchard Farm "WIBO", Mr. Witold Kulesza from Stelmachów, it was possible to set up the sorption barrier made of compost from Sokółka around the real object. The barrier was installed in Folwarki Tylwickie, where active burial ground consisting of three tanks built of concrete well circles isolated with roofing paper and cement as well as non-hermetic ground pits, still works. It is from the $1^{\text {st }}$ category of threat. Analyzed tanks are of the following capacities: $1.26,1.8$, and $1.8 \mathrm{~m}^{3}$. According to the cataloguing in 2009, the burial ground holds almost $2.3 \mathrm{Mg}$ of outdated pesticides, while estimated weight of dangerous pesticide wastes to neutralize amounts to $43.3 \mathrm{Mg}$. The burial ground functions at the depth of about $1.6 \mathrm{~m}$, while underground waters can be found at $2 \mathrm{~m}$ level. It is situated among undergrowth directly in the cultivated field and near protected areas and compact building. Stabilized sewage sludge and its composts applied in the study can be also used to fill the ground pits formed after burial grounds close down, and to reclamation of the surrounding area. Due to their beneficial sorption properties, it would additionally prevent surrounding environment from migration of pesticide remains and would make costs of the object liquidation lower.

In future, the research can find its application to reduce the spread of other toxic substances within the environment during an ecological disaster or a poison leakage.

\section{Acknowledgments}

Financial support for this research was provided by Ministry of Science and Higher Education within the project N N304 274840.

\section{REFERENCES}

1. 8th International $\mathrm{HCH}$ and Pesticides Forum Sofia, Bułgaria 26-28.05.2005.

2. Atkins P.W. 2006. Physical chemistry, 8th ed. Oxford University Press.

3. Biziuk M., Kosikowska M. 2009. Methods of determination of pesticides residues - a review Ecological Chemistry and Engineering S, 16 (32), 207-220.

4. Feng K., Yu B.Y., Ge D.M., Wong M.H., Wang X.C., Cao Z.H. 2003. Organo-chlorine pesticide (DDT and $\mathrm{HCH}$ ) residues in the Taihu Lake Region and its movement in soil-water system - I. Field survey of DDT and HCH residues in ecosystem of the region. Chemosphere, 50(6), 683-687.

5. Ignatowicz K. 2007a. Content of harmful substances in natural environment elements near pesticide tomb. Oceanological and Hydrobiological Studies, Vol. XXXVI, 3, 163-170.

6. Ignatowicz K. 2007b. Evaluation of pesticide remains and heavy metals concentrations near burial grounds. Polish Journal of Environmental Studies, 16 (3B), 177-181. 
7. Ignatowicz K. 2007c. Określenie wielkości migracji pozostałości pestycydów i metali ciężkich z mogilników do wód naturalnych. Rocznik Ochrona Środowiska, 9, 281-293.

8. Ignatowicz K. 2008a. Sorption process for migration reduction of pesticides from graveyards. Archives of Environmental Protection, 34(3), 143-149.

9. Ignatowicz K. 2008b. Zastosowanie sorpcji na odpadowych materiałach naturalnych do ograniczenia migracji pestycydów z mogilników. Przemysł Chemiczny.

10. Ignatowicz K. 2008c. Zanieczyszczenie wód podziemnych i powierzchniowych środkami ochrony roślin $\mathrm{w}$ pobliżu mogilnika pestycydowego. Gaz, Woda i Technika Sanitarna, 9, 13-15.

11. Ignatowicz K. 2009a. Selection of sorbent for removing pesticides during water treatment. Journal of Hazardous Materials, 169, 953-957.

12. Ignatowicz K. 2009b. Sewage sludge compost applying for migration reduction of pesticide from graveyards. Polish Journal of Environmental Studies. Series of Monographs, 6, 49-54.
13. Ignatowicz K. 2011a. A mass transfer model fort he adsorption of pesticide on coconut shell based activated carbon. International Journal of Heat and Mass Transfer, 54, 4931-4938.

14. Ignatowicz K. 2011b. Application of Sokółka compost to pratect pesticide graveyard area. Rocznik Ochrona Srodowiska, 13, 1201-1221.

15. Li W., H. Yang, Q. Gao, H. Pan, H. Yang, 2012. Residues of Organochlorine Pesticides in Water and Suspended Particulate Matter from Xiangshan Bay, East China Sea. Bull Environ Contam Toxicol 89, 811-815.

16. Siłowicki A. 2003. Iwentaryzacja odpadów środków ochrony roślin Mat. IOR, projekt w ramach Projektu GEF w Polsce.

17. Spadotto C.A., Hornsby A.G., 2003. Soil sorption of acidic pesticides: modeling $\mathrm{pH}$ effects. Journal Environmental Quality, 32, 949-995.

18. Wiater J., 2007. Assessment of manurial value of composts made from municipal wastes. Pol. J. Environ. Stud., 16(2A), 707-710. 